\title{
Analisis Penerapan Prinsip Retorika di Panggung Debat Antar Calon Gubernur DKI Jakarta 2017
}

\author{
Fathurrijal ${ }^{\mathrm{a}, 1, *}$ \\ *Program Studi Komunikasi Penyiaran Islam, Fakultas Agama Islam Universitas Muhammadiyah Mataram,83115, \\ Indonesia \\ Fathur_mujaddid@yahoo.co.id
}

INFO ARTIKEL ( 8 pt)

Riwayat Artikel:

Diterima: Juni 2019

Direvisi : Juli 2019

Disetujui: Agustus 2019

Kata Kunci:

Retorika,

Debat,

Demokrasi,

Pilkada,

Keywords:

Rhetoric,

Debate,

Democracy,

Regional Election,
ABSTRAKSI

Abstrak: Pemilihan kepala daerah yang dilaksanakan di semua daerah, baik provinsi dan kabupaten kota di Indonesia telah menjadi panggung politik yang mempertontonkan kualitas visi-misi calon kepala daerah, di dalamnya terdapat momentum menarik yang ditunggu-tunggu oleh masyarakat pemilih, momentum debat antar calon gubernur atau calon bupati/wali kota. Dalam momentum debat antar kandidat ini, kemampuan retoris kandidat sebagai peserta kontestasi demokrasi diuji dihadapan publik secara langsung dan disiarkan melalui televisi, radio, media sosial dan jejaring internet lainnya. Tulisan ini, memotret suasana kemampuan retoris para kontestan yang berkompetisi memperebutkan kursi gubernur dan kursi wakil gubernur DKI tahun 2017 lalu. Seperti apa penerapan perinsip-perinsip retorika selama debat antar kandidat berlangsung itulah yang dielaborasi dalam tulisan ini

Abtsract: Regional head elections held in all regions, both provinces and regency cities in Indonesia have become a political stage that shows the quality of the vision and mission of regional head candidates, in which there is an interesting momentum eagerly awaited by the voting community, debating momentum between prospective governors or candidates regents / mayors. In the momentum of the debate between candidates, the candidate's rhetorical ability as a participant in democratic contestation is tested before the public directly and broadcast via television, radio, social media and other internet networks. This paper, photographing the atmosphere of the rhetorical ability of the contestants who competed for the governor's chair and the deputy governor's seat in 2017 last year. What is the application of the principles of rhetoric during debates between candidates that are elaborated in this paper.

\section{Pendahuluan}

Pemilihan umum kepala daerah (Pemilukada) DKI Jakarta adalah salah satu momentum penting bagi masyarakat ibu kota untuk melahirkan pemimpin ibu kota negara yang kredibel, kapabel dan berkualitas. Selain sebagai amanah konstitusi seperti yang tetrtuang dalam pasala 18 ayat (4) UUD 1945 'Gubernur, Bupati, dan Walikota masing-masing sebagai kepala daerah provinsi, kabpuaten, dan kota dipilih secara demokratis.

Pemilihan Gubernur DKI Jakarta 2017 ini pada hakekatnya adalah etalase atau cerminan demokrasi secara keseluruhan di negeri ini. Oleh sebab itu, pelakasanaannya benar-benar menguras perhatian semua pihak, termasuk kalangan akademisi tidak mau ketinggalan untuk tidak mengamati, mengomentari proses demi proses dari pemilihan gubernur DKI 2017.

Pemilihan Gubernur DKI Jakarta 2017 adalah salah satu fenomena besar dan bersejarah, yang menyedot perhatian publik dari Sabang sampai Merauke, hampir semua mata tertuju pada perhelatan lima tahunan ini. Padahal pada saat dan waktu bersamaan pemilihan Gubernur dan 
Bupati, Walikota juga sedang berlangsung di daerah lain. sebelum hari pemilihan, terlebih dahulu diawali dengan debat antar kandidat yang dipasilitasi oleh Komisi Pemilihan Umum (KPU) DKI Jakarta, debat antar kandidat adalah salah satu momen paling menarik dan ditunggu-tunggu oleh masyarakat pemilih. Pada moment debat antar kandidat inilah, masyarakat pemilih memperoleh keyakinan atas kemampuan setiap calon gubernur DKI Jakarta.

Momen debat antar kandidat tentu menjadi momen krusial bagi para kandidat cagub-cawagub DKI 2017, sebab bila setiap ide pemikiran dan solusi yang ditawarkan tidak mampu meyakinkan para pemilih, maka dengan sendirinya kandidat akan ditinggalkan oleh pemilih mencari kandidat yang lebih pantas dan pas. Oleh sebab itu, kemampuan setiap kandidat mengemas pesan visi-misi serta program kerja yang sudah dituangkan didalam kertas berlembar-lembar harus diterjemahkan dan dibahasakan melalui bahasa oral dengan retorika yang bernilai magis, retorika yang mampu menghipnotis dan mampu memantapkan keyakinan pemilihnya.

Kelebihan dan kekurangan yang divisualkan oleh setiap kandidat dalam debat, sangat berpengaruh pada kepercayaan publik sebagai pemilih kepada para kontestan yang berkompetisi. Oleh sebab itu, bila setiap kontestan menginginkan dukungan maksimal dari pemilih, maka selain modal besar, juga penting bagi para kontestan untuk memperbesar kapasitas kemampuan retorisnya.

Perlu dicatat, bahwa kehidupan modern sekarang ini, tidak pernah luput dari aktivitas dan kesempatan-kesempatan berbicara di depan publik atau depan orang banyak. Semua kehidupan ini tidak luput dari aktivitas tersebut, tidak terkecuali aktivitas-aktivitas politik praktis, pendidikan, dakwah dan lain sebagainya.

Retorika tidak dapat dipisahkan dengan kehidupan manusia. Retorika merupakan kebutuhan manusia. Aktivitas retoris, banyak ragamnya. Ada canda, obrolan, basa-basi, tegur-sapa, khutbah, kampanye, diskusi, seminar, konferensi, dan lain-lain. Dengan demikian pada dasarnya retorika itu menjadi bagian yang tidak dapat dipisahkan dengan kehidupan masyarakat. Adapun retorika politik yang dimaksudkan dalam kajian ini adalah retorika yang bertujuan politis, dimana politik itu sendiri adalah siapa memperoleh apa, kapan, dan bagaimana, pembagian nilai-nilai oleh yang berwenang, kekuasaan dan pemegang kekuasaan, pengaruh, tindakan yang diarahkan untuk mempertahankan dan atau memperluas tindakan lainnya (Nimmo, 2005).

Retorika merupakan seni berbicara dihadapan orang banyak atau juga disebut sebagai public speaking. Secara mendalam, retorika merupakan keterampilan seseorang dalam berbicara menyampaikan informasinya secara langsung kepada khalayak yang meliputi pilihan kata yang efektif, kalimat demi kalimat, intonasi/penekanan suara, ekspresi wajah, bahasa tubuh, wawasan, ingatan, kesungguhan dan totalitas. Retorika bukan hanya berarti kemampuan berbicara/pidato yang lancar, tetapi kemampuan berbicara/pidato secara singkat, jelas, padat, persuasif dan mengesankan. Dalam kegiatan komunikasi politik yang bersifat persuasif, retorika merupakan modal yang sangat penting. Kegiatan komunikasi massa (kampanye, program debat televisi, rapat umum, dll) dan kegiatan propaganda akan lebih mudah membuahkan sukses apabila disokong dengan retorika yang handal dari seorang politisi.

Retorika memiliki banyak manfaat, sebagaimana yang dijelaskan oleh Aristoteles yang dikutip oleh Martha (2010), Pertama, retorika menuntun penutur dalam mengambil keputusan. Apa yang terjadi dalam kehidupan ini, menurut Aristoteles ada hal-hal yang memang benar dan ada hal-hal yang memang tidak benar tetapi cenderung mengalahkan lawannya tanpa mempertimbangkan kebenaran. Yang pertama tampak misalnya pada fakta-fakta kehidupan, sedang yang kedua terlihat dari perwujudan perasaan atau appeal negatif terhadap fakta-fakta tersebut. Misalnya: ketidaksukaan, kemarahan, prasangka, dan sebagainya. Hal-hal yang benar pasti akan muncul karena bagaimanapun kebenaran akan mengalahkan ketidakbenaran. Di samping itu, semua manusia mempunyai instink alamiah tentang kebenaran yang dapat menunjukkan mana yang benar dan mana yang tidak benar. Karena itu, jika dalam kegiatan bertutur, penutur salah dalam mengambil keputusan karena didorong oleh appeal negatif atau cenderung ingin menang saja, maka dia akan digilas oleh pilihannya itu. Untuk menyelamatkan penutur dari kemungkinan itu, 
Aristoteles menegaskan kembali bahwa retorika adalah sarana yang dapat menuntun penutur dalam mengambil keputusan yang benar.

Kedua, retorika mengajar penutur dalam memilih argumen. Menurut Aristoteles, argumen dibedakan menjadi dua jenis, yakni argumen artistik dan argumen nonartistik. Argumen artistik diperoleh dari pokok persoalan atau topik yang ditampilkan, sedang argumen nonartistik diperoleh dengan melihat fakta-fakta yang ada di sekitar topik, baik yang terkait langsung maupun yang tidak terkait langsung dengannya. Misalnya, untuk topik dengan tujuan pengarahan, maka argumen nonartistiknya antara lain: kondisi ekonomi, politik, keamanan, perundang-undangan, dan lain-lain.

Ketiga, retorika mengajar penutur dalam mempersuasi. Dalam hubungan ini, tampak sekali misalnya ketika retorika mengajarkan bagaimana menata tuturan secara sistematis, memilih materi bahasa yang tepat untuk mewadahi unit-unit topik, dan menampilkannya menurut cara-cara yang efektif.

Keempat, retorika membimbing bertutur secara rasional. Seperti telah disebut di atas, bahwa dalam realitas kehidupan ada sesuatu yang benar, dan ada sesuatu yang salah tetapi diperjuangkan. Karena itu, untuk memperjuangkan kebenaran yang pertama demi mengimbangi kesesatan yang dibenar-benarkan, seorang penutur perlu memanfaatkan retorika. Dengan bertutur secara rasional inilah, penutur akan sangat dibantu menghindari kekonyolan-kekonyolan yang mungkin ia buat, sebagai akibat ketidakmampuannya menuturkan topik itu. Keuntungan lain, bahwa tuntunan rasional akan mempercepat tersingkapnya ketidakbenaran. Dalam konteks politik praktis, seperti kampanye politik yang didalamnya terdapat debat terbuka antar calon gubernur-caalon wakil gubernur di depan publik, baik langsung dan tidak langsung mampu memberikan manfaat bagi setiap kontestan yang berkompetisi.

Menurut Martha (2010) peranan faktor watak penutur sangat penting dalam setiap peristiwa tutur. Karena dengan sekali saja penutur membohongi pendengarnya, maka etika dan kejujurannya akan terbongkar. Imajinasi terhadap jiwa pendengar juga tidak bisa diabaikan, sebab hal ini akan dapat merebut simpati pendengarnya. Peranan gaya penampilan juga tidak bisa dikesampingkan, karena hal itu akan sangat membantu pendengar untuk memahami suatu topik. Sedangkan kekuatan bukti-bukti dan argumen berfungsi untuk meningkatkan daya persuasi. Oleh sebab itu, sebagaimana yang disarankan oleh Aristoteles ada baiknya setiap penutur menampilkan alasanalasan yang logis, memahami kejiwaan manusia pada umumnya, dan memiliki rasa tentang apa yang baik dan sebaiknya, serta dapat memahami emosi pendengar. Ketika ia berada dan berhadapan dengan publik. Politik praktis tidak pernah luput dari aktivitas retorika, dalam catatan sejarah yang penulis baca dari beberapa literatur disebutkan bahwa, Bidang politik adalah salah bidang kegiatan yang pertama-tama memanfaatkan retorika secara terencana.

Sampai saat ini retorika dimanfaatkan dalam bidang politik. Propaganda-propaganda politik, kampanye-kampanye menjelang pemilu di negara yang menganut pemerintahan demokrasi adalah bukti pemanfaatan retorika di bidang politik. Politik memanfaatkan retorika untuk mempengaruhi rakyat dengan materi bahasa, ulasan-ulasan, dan gaya bertutur yang meyakinkan perhatian pemilih. Propaganda itu kadang-kadang berhasil mengubah pendirian rakyat kadang-kadang tidak. Ini bergantung pada tingkat pendidikan dan kecerdasan rakyat yang ingin dipengaruhi. Kemampuan retorika dan kelihaian setiap kandidat dapat dilihat dari seberapa besar dukungan dari masyarakat pemilih.

Pemilihan kepala Daerah DKI Jakarta 2017 diikuti oleh pasangan Agus Harimurti Yudhoyono-Sylviana Murni, pasangan Basuki Tjahaja Purnama-Djarot Saiful Hidayat dan pasangan Anies Baswedan-Sandiaga Uno. Masing-masing kandidat gubernur DKI Jakarta memiliki kelebihan dan kekurangan dalam penggunaan retorika pada saat debat berlangsung.

Dalam penelitian ini, yang dielaborasi adalah bagaimana calon gubernur dan calon wakil gubernur DKI Jakarta 2017 mengemas pesan-pesan dan janji-janji politiknya ke dalam retorika pada saat debat. Dalam debat antar kandidat yang diselenggarakan oleh KPU DKI Jakarta 2017, dapat dilihat bahwa di dalamnya ada pertarungan argumentasi, konsep dan program melalui 
penggunaan prinsip-prinsip retorika. Prinsip-prinsip retorika yang dimaksud dalam penelitian ini adalah penerapan kanun retorika dalam tata bahasa yang digunakan oleh setiap kandidat, dalam memaparkan program dan janji politiknya kepada pemilih. Untuk mengetahui penerapan prinsip dan perbedaan tersebut, bahan-bahan retorika politik setiap kandidat akan dipilah terlebih dahulu dari rekaman video yang didapatkan dari TV One.

\section{Kajian Teoritik}

\section{A. Prinsip-Prinsip Retorika}

Ada dua aspek yang harus diperhatikan dalam retorika ini yaitu, pertama, pengetahuan mengenai bahasa dan penggunaan bahasa dengan baik. Kedua, pengetahuan mengenai objek tertentu yang akan disampaikan dengan menggunakan bahasa yang baik (Keraf, 2007).

Dalam pandangan Aristoteles, Retorika meruapakan alat persuasi yang tersedia. Maksudnya, seorang pembicara yang tertarik untuk membujuk khalayaknya harus mempertimbangkan tiga bukti retoris, Logika (Logos), Emosi (Pathos), dan Etika/kredibilitas (Ethos) (Richard West dan Lynn Turner, 2008).

Aristoteles menyebut bahwa suatu orasi atau pidato dapat menjadi efektif, maka orator atau pembicara harus mengikuti tuntunan atau prinsip-prinsip retorika, Aristoteles menyebutnya sebagai kanon, agar orasi atau pidato lebih menggugah, aturan-aturan atau hukum ini harus diterapkan, kanon-kanon ini telah banyak diterapkan di dalam beberapa situasi berbicara (West dan Turner (2008).

Ada lima tahap penyusunan pidato yang dikenal dengan lima hukum Retorika "The Five Cannons of Rhetorica", yaitu sebagai berikut:

\begin{tabular}{|c|c|c|}
\hline Kanon & Definisi & Deskripsi \\
\hline Inventio (Penemuan) & $\begin{array}{l}\text { Integrasi cara berfikir dan } \\
\text { argument di dalam pidato }\end{array}$ & $\begin{array}{l}\text { Menggunakan logika dan bukti di } \\
\text { dalam pidato membuat sebuah } \\
\text { teks pidato menjadi lebih kuat dan } \\
\text { persuasive. }\end{array}$ \\
\hline $\begin{array}{l}\text { Disposito } \\
\text { (Penyusunan/pengaturan) }\end{array}$ & Organisasi dari pidato & $\begin{array}{l}\text { Mempertahankan struktur suatu } \\
\text { pidato-pengantar, batang tubuh, } \\
\text { kesimpulan-mendukung } \\
\text { kredibelitas pembicara, menambah } \\
\text { tingkat persuasi dan mengurangi } \\
\text { rasa frustrasi pada pendengar. }\end{array}$ \\
\hline Elocutio (Gaya) & $\begin{array}{l}\text { Penggunaan bahasa di } \\
\text { dalam pidato }\end{array}$ & $\begin{array}{c}\text { Penggunaan gaya memastikan } \\
\text { bahwa suatu pidato dapat diingat } \\
\text { dan bahwa ide-ide dari pembicara } \\
\text { diperjelas. }\end{array}$ \\
\hline Pronountiatio (Penyampaian) & Presentasi dari pidato & $\begin{array}{c}\text { Penyampaian yang efektif } \\
\text { mendukung kata-kata pembicara } \\
\text { dan membantu mengurangi } \\
\text { ketegangan pembicara }\end{array}$ \\
\hline Memoria (Ingatan/Memori) & $\begin{array}{l}\text { Penyimpanan informasi di } \\
\text { dalam benak pembicara }\end{array}$ & $\begin{array}{c}\text { Mengetahui apa yang akan } \\
\text { dikatakan dan kapan } \\
\text { mengatakannya meredakan } \\
\text { ketegangan pembicara dan } \\
\text { memungkinkan pembicara untuk } \\
\text { merespon hal-hal yang tidak } \\
\text { terduga }\end{array}$ \\
\hline
\end{tabular}

Tabel: Kanon-kanon Retorika Aristoteles

(Sumber: West dan Turner, 2008:11-15)

Istilah-istilah latin dalam hukum retorika tersebut dijelaskan oleh Gun dan Zarkasy (2012) sebagai berikut: 
1) Inventio (penemuan). Pada tahap ini, orator atau pembicara memilih topik dan meneliti audiens untuk mengetahui metode persuasi yang paling tepat. Bagi Aristoteles, retorika tidak lain dari kemampuan untuk menentukan dalam kejadian tertentu dan situasi tertentu dengan metode persuasi yang ada. Dalam tahap ini juga, pembicara merumuskan tujuan dan mengumpulkan bahan (argumen) yang sesuai dengan kebutuhan khalayak.

2) Disposito (Penyusunan/pengaturan). Pada tahap ini, orator atau pembicara menyususun pidato atau mengorganisasikan pesan. Aristoteles menyebutnya taxis yang berarti pembagian. Pesan harus dibagi ke dalam beberapa bagian yang berkaitan dengan logis. Susunan berikut mengikuti kebiasaan berpikir manusia, yaitu pengantar, pernyataan, argumen, dan epilog.

3) Elocutio (Gaya). pada tahap ini, pembicara memilih kata-kata dan menggunakan bahasa yang tepat untuk mengemas pesannya. Aristoteles memberikan nasihat, gunakan bahasa yang tepat, benar, dan dapat diterima, yaitu pilih kata-kata yang jelas dan langsung, sampaikan kalimat yang indah, mulia dan hidup: dan sesuaikan bahasa dengan pesan, khalayak, dan pembicara.

4) Memoria (Ingatan/Memori) pada segmen ini, pembicara harus mengingat apa yang ingin disampaikannya dengan mengatur bahan-bahan pembicaranya.

5) Pronountiatio (Penyampaian) pada segmen ini, pembicara menyampaikan pesannya secara lisan. Di sini, akting sangat berperan. Pembicara harus memerhatikan oleh suara dan gerakan-gerakan anggota badan..

\section{B. Tipe Orator Politik}

Dalam Public Relations politik, dibutuhkan kesadaran diri bahwa seorang Public Relations akan membawa nama lembaga yang diwakilinya atau menunjukkan citra kandidat yang didukungnya. Oleh karena itu, harus senantiasa menyadari tipologi orator yang sedang diperankannya. Tipologi orator dalam Public Relations politik itu antara lain seperti berikut:

1) Noble Selves: orang yang menganggap dirinya paling benar, mengklaim lebih hebat dari yang lain dan sulit menerima kritik. Jika tipe ini yang ada dalam diri praktisi Public Relations Politik, maka tentu akan menghambat proses Public Relations politik yang sedang dilakukan.

2) Rhetorically Reflector: orang yang tidak punya pendirian yang teguh, hanya menjadi cerminan orang lain. Tipe seperti ini akan melemahkan lembaga atau kandidat, karena orator tak memiliki kapasitas untuk membangun diskursus, berpolemik atau mempertahankan ide dan konsep. Dia tak lebih dari sekedar cerminan kepentingan pihak lain.

3) Rhetorically Sensitive: orang yang adaptif, dan cepat menyesuaikan diri dengan lingkungannya. Ini merupakan tipe ideal karena tahu bagaimana dan kapan harus memainkan diri publik (public self) dan diri pribadi (private self). Cenderung fleksibel, tetapi memiliki konsep diri yang jelas, sehingga bisa menunjukkan ketegasan dan kewibawaannya di depan khalayak.

\section{Jenis Retorika Politik}

Jenis retorika politik persepktif Aristoteles dapat diklaisifikasikan sebagai berikut: 


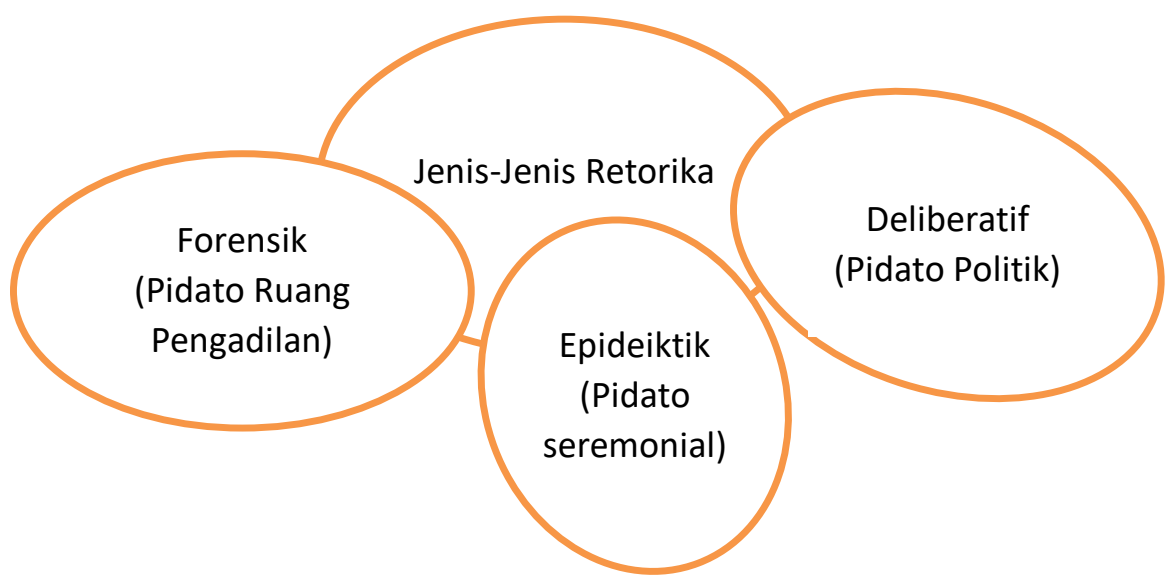

Figura:

Jenis-Jenis Retorika Politik

(Sumber: West dan Turner, 2008)

Retorika Deliberatif. Retorika Deliberatif dirancang untuk mempengaruhi orang-orang dalam masalah kebijakan pemerintah dengan menggambarkan keuntungan dan kerugian relatif dari caracara alternatif dalam melakukan segala sesuatu. Fokusnya ialah pada apa yang akan terjadi di masa depan jika di tentukan kebijakan tertentu. Seorang politisi dalam hal kajian ini dituntut mampu menciptakan dan memodifikasi pengharapan atas hal-hal yang akan datang. Di dalam seluruh tahap politik kita melihat retorika deliberatif.

Retorika Forensik. Retorika Forensik berfokus pada apa yang terjadi pada masa lalu untuk menunjukkan bersalah atau tidak bersalah, pertanggungjawaban, atau hukuman dan ganjaran. Setting-nya yang biasanya adalah ruang pengadilan, tetapi terjadinya di tempat lain.

Retorika Demonstratif. Retorika Demonstratif adalah wacana yang memuji dan menjatuhkan. retorika ini juga sering disebut dengan Retorika epideiktik. Tujuannya adalah untuk memperkuat sifat baik dan sifat buruk seseorang, suatu lembaga, atau gagasan. Kampanye politik penuh dengan retorika demonstratif seperti satu pihak menantang kualifikasi pihak lain bagi jabatan di dalam pemerintahan. Dukungan editorial oleh surat kabar, majalah, televisi, dan radio juga mengikuti garis demonstratif, memperkuat sifat-sifat positif kandidat yang didukung dan sifat-sifat negatif lawannya.

\section{Penyajian dan Analisis Data}

\section{A. Penerapan Prinsip-Prinsip Retorika}

Pada bagian ini, dielaborasi secara ringkas, temuan terkait dengan penerapan kelima prinsip dan tipe retorika calon gubernur dan calon wakil gubernur DKI 2017, dari penampilan dalam video debat yang penulis dapatkan dari TV One, calon gubernur dan calon wakil gubernur DKI Jakarta mampu menerapkan prinsip-prinsip retorika dalam menyampaikan pendapat, argument, sanggahan dan pertanyaan yang disampaikannya kepada sesama kandidat.

Adapun tema debat terakhir pada putaran pertama pilkada DKI Jakarta telah ditentukan oleh KPU DKI Jakarta, yakni masalah 'Kependudukan, Perlindungan Anak, Pemberdayaan Perempuan, Antinarkoba, dan Kebijakan terhadap Penyandang Disabilitas'. Berikut adalah penerapan prinsip retorika oleh calon gubernur DKI Jakarta 2017

\section{1) Retorika Politik Pasangan Agus Harimurti Yudhoyono - Silviana Murni}

Agus Harimurti dan Silvyana adalah pendatang baru dalam dunia politik praktis di DKI Jakarta, keduanya belum memiliki talenta politik yang maksimal dalam mengurai permasalahan-permasalahan ibu kota dan permasalahan masyarakat secara umum, tentu dengan pengalaman minimalis dalam politik praktis itu ikut berpengaruh pada gaya retoris kedua pasangan ini. Namun walau dicatat sebagai pendatang baru dalam politik praktis, penampilan 
kedua pasangan ini memiliki daya hentak yang cukup untuk membuat kandidat lain tidak bisa menganggap remeh perpoma debatnya.

a. Inventio (Penemuan).

Dalam video debat memperlihatkan, pasangan Agus Harimurti Yudhoyono dan Silvyana Murni yang dicatat sebagai pendatang baru ini, berhasil tampil dengan sangat baik, walau terkesan menghafal.

b. Disposito (penyusunan).

Pada tahap ini, sesekali pasangan Agus-Silvy terlihat mencatat dan menuliskan pesanpesan apa yang akan disampaikan pada saat debat.

c. Elocutio (Gaya).

Pada tahap ini, kedua kandidat memilih kata-kata dan menggunakan bahasa yang tepat untuk mengemas pesannya. Pilihan kata atau diksi pasangan Agus-Silvy dalam menyampaikan pesan dan statemen politiknya sesekali mengulang kata yang digunakan pada penjelasan sebelumnya, selain itu, dari Silvy juga terdengar sering terdengar kata "lho".

d. Memoria (Memori).

Penampilan Agus Harimurti Yudhoyono dan Silvyana Murni yang terkesan sebagai seorang memoriter dalam setiap debat, kali ini penampilannya dalam debat terakhir, tidak terkesan menghafal, namun dikombinasikan dengan catatan-catatan kecil yang dipegang terutama oleh Silvy. Kebiasaan pasangan ini tidak pernah menggunakan teks atau dokumen catatan di setiap penyampaian pesan politiknya saat debat berlangsung.

e. Pronountiatio (Penyampaian).

Pada tahapan ini, pasangan Agus Harimurti Yudhoyono dan Silvyana Murni, menyampaikan pesannya secara lisan. Dengan sesekali menggerakkan anggota badannya.

\section{2) Retorika Politik Pasangan Basuki Tjahaja Purnama - Djarot Saiful Hidayat}

Pasangan calon gubernur dan calon wakil gubernur ini, adalah politikus senior yang telah banyak memiliki pengalaman yang maksimal dalam politik praktis di tingkat lokal, keduanya memiliki pengalaman menata kabupaten kota di tempat masing-masing, kemudian menjadi legislator di senayan, fungsionaris partai politik. Status petahana membuat kedua kandidat ini, dalam konteks debat, sulit dikalahkan, karena sudah banyak memiliki amunisi untuk menangkal pernyataan, pertanyaan, sanggahan dari lawan debat.

a. Inventio (Penemuan).

Kedua pasangan ini meruapakan pasangan incumbent, maka nyaris tidak ada yang baru, seperti apa yang dilontarkan oleh pasangan Agus-Silvy saat debat. Pasangan nomor urut 2 ini tidak memiliki penemuan-penemuan, namun yang ada adalah penyampaian program-program yang sudah ada dan akan dilanjutkan bila mereka terpilih sebagai gubernur.

b. Disposito (penyusunan).

Dari data-data berupa alat peraga, gambar dan data yang ditampilkan saat debat berlangsung, pasangan ini sudah sangat siap dalam menjelaskan program-program kerja dan visi-misi politiknya. Apa yang akan disampaikan di dalam debat sudah disusun secara rapi. 
c. Elocutio (Gaya).

Pada tahap ini, pembicara memilih kata-kata dan menggunakan bahasa yang tepat untuk mengemas pesannya.

d. Memoria (Memori).

Pasangan Basuki-Djarot bukanlah tipe memoriter yang baik, dalam konteks debat terakhir, pasangan ini banyak menampilkan data-data yang sudah dipersiapkan.

e. Pronountiatio (Penyampaian).

Pada tahap ini, Pasangan Basuki-Djarot, menyampaikan pesannya secara lisan. Cenderung tidak menghargai sanggahan dan tanggapan dari kandidat lain. Salah satu karakteristik kedua pasangan ini adalah meledak-ledak dalam menyampaikan pesan-pesan politik, dan dalam memberikan pertanyaan atapun sanggahan. Model penyampaian ini, bagi sebagian kalangan pemilih malah dijadikan medium persuasi pemilih untuk berpindah ke kandidat lainnya

\section{3) Retorika Politik Pasangan Anues Rasyid Baswedan - Sandi Salahuddin Uno}

Kedua kandidat ini, dari pengalaman politik praktis sangat maksimal, sama dengan pasangan Basuki dan Djarot, keduanya memiliki pengalaman mengurus birokrasi, baik di dunia pendidikan, bisnis dan politik. Kombinasi keduanya yang berangkat dari jalur akademisi (Anies Baswedan), Sandi Uno berangkat dari bisnis dan politisi partai gerindra, menjadikan pasangan ini cepat menguasai panggung debat, baim narasi dan diksi yang digunakan dalam orasinya menguatkan prinsip-prinsip retoris dipraktekkan dan berjalan dengan baik.

a. Inventio (Penemuan).

Sebagai pendatang baru dalam politik ibu kota, Anies-Sandi dalam debatnya beberapa kali memperlihatkan data-data temuannya terkait froblematika yang masih belum terselesaikan di Jakarta oleh pemimpin sebelumnya. Misalnya, Anies menyebutkan data prefalensi Narkoba di DKI Jakarta masih merupakan yang tertinggi, kemudian temuan lainnya yang diperlihatkan oleh pasangan ini adalah permasalahan transportasi yang tidak bersahabat dengan penyandang disabilitas, dan ibu hamil. Kemudian Sandi, sering menyebut nama warga yang dia temui untuk dijadikan data temuan, bahwa di Jakarta masih warga yang memiliki kepedulian, masih ada warga Jakarta yang sampai saat ini mash dihantui oleh Pol PP karena sewaktu-waktu mereka digusur. Dengan data-data tersebut, pasangan ini mampu mempersuasi pemilih, untuk mengalihkan pilihan kepada pasangan ini.

b. Disposito (penyusunan).

Dari kematengan bahasa dan gaya retorika pasangan Anis-Sandi, tentu mempersiapkan diri sebelum tampil, walau pasangan ini bukan incumbent, namun dari data-data yang ditunjukkan ke publik, hampir mendekati kesamaan dengan pasangan nomor urut dua, yang kaya dengan data-data.

c. Elocutio (Gaya).

Pada tahap ini, pasangan Anies-Sandi bisa dikatakan sebagai pemenangnya, karena memiliki gaya presentasi berbeda dengan kedua kandidat lainnya, untuk menarik perhatian penonton maupun pemilih DKI Jakarta, Sandi memiliki inovasi gaya yang sangat luar biasa, dimana dia dengan spontanitas mencopot sepatu yang dikenakan, dan menegaskan dengan gaya bahasa yang lugas, bahwa sepatu ini adalah karya anak-anak muda Jakarta yang kreatif dan tergabung dalam program oke-oce. Pasangan ini berhasil menjadi pembicara yang mampu memilih kata-kata dan menggunakan bahasa yang tepat untuk mengemas pesan-pesan politiknya. 
d. Memoria (Memori).

Pasangan Anies-Sandi dapat digolongkan sebagai memoriter, karena tidak pernah menggunakan teks dalam menyampaikan pesan-pesan politiknya.

e. Pronountiatio (Penyampaian).

Pada tahap ini, Pasangan Anies-Sandi, menyampaikan pesannya secara lisan. Baik anies maupun sandi, keduanya sama-sama lebih tertata dalam menyampaikan pesan dan program-program politiknya pada saat menanggapi, menjawab dan menjelaskan pertanyaan dan sanggahan dari kandidat lainnya. Intonasi suara kedua kandidat yang bersahabat ini datar dan tidak meledak-ledak. Sehingga apa yang disampaikan enak disimak dan dinikmati.

\section{B. Tipe Retorika Politik Cagub - Cawagub DKI}

Dalam terori retorika politik, setidaknya ada tiga tipe retorika yang dapat digunakan untuk menilai retorika cagub-cawagub DKI Jakarta 2017.

Pertama, retorika deliberative, retorika tipe ini dikemas oleh orator untuk mempengaruhi orang banyak dalam masalah kebijakan pemerintah dengan menggambarkan keuntungan dan kerugian relative dari cara-cara alternative dalam melakukan segala sesuatu. Kedua, retorika forensik, retorika tipe ini menegaskan bahwa orator fokus pada apa yang telah terjadi pada masa lalu untuk menunjukkan kekeliruan ataupun kesalahan atau sebuah kebenaran, pertanggung jawaban, atau hokum dan ganjaran. Ketiga, retorika demonstrative, adalah tipe retorika dari seorang orator yang cenderung memuji dan menjatuhkan.

Bila mengacu pada teori di atas, maka retorika politik calon gubernur dan calon wakil gubernur DKI 2017 dalam debat antar kandidat pada pemilihan putaran pertama, bisa digambarkan sebagai berikut.

\section{1) Agus Harimurti Yudhoyono - Sylviana Murni}

Retorika deliberative, retorika tipe ini, fokusnya pada apa yang akan terjadi di masa depan jika di tentukan kebijakan tertentu. Seorang politisi dituntut mampu menciptakan dan memodifikasi pengharapan atas hal-hal yang akan datang. Pasangan calon, Agus Harimurti Yudhoyono dan Silvyana Murni. Memberikan harapan di masa datang bagi warga Jakarta bila dia terpilih menjadi gubernur dan wakil gubernur. Harapan-harapan yang diberikan pasangan calon ini, dapat dilihat pada statemen dan komitmen politiknya ketika menjawab pertanyaan dari tim panelis ketika ditanya pandangannya terkait keberadaan sektor informal di Jakarta sebagai bagian sumber daya perkotaan, dan bagaimana langkahnya untuk mengembangkan sektor informal dalam meningkatkan kualitas hidup baik pada individu maupun sosial.

'Dalam program kami secara spesifik, kami ingin mengembangkan warga dalam UMKM. Kami memiliki dana bergulir, skema bantuan modal usaha yang bisa diberikan secara tepat sasaran untuk bisa mengembangkan UMKM yang baru maupun yang sudah ada saat ini. Kita juga ingin menata dan mengembangkan PKL, mereka tidak untuk digusur tetapi untuk dikembangkan dan diberdayakan, Dan kami ingin sekali lagi melibatkan seluruh elemen masyarakat, kami juga memahami bahwa industri kreatif di Jakarta juga sangat potensial'. (Sumber: Video Debat)

Retorika Forensik berfokus pada apa yang terjadi pada masa lalu untuk menunjukkan bersalah atau tidak bersalah, pertanggungjawaban, atau hukuman dan ganjaran. Pasangan Agus-Silvy terlihat menerapkan retorika tipe forensik ini pada sesi interaksi atau saling bertanya dan saling menanggapi pertanyaan antar kandidat. Dimana saat Silvy bertanya kepada pasangan Basuki-Djarot, terkait komitmen pasangan Patahana ini terhadap perlindungan terhadap kaum perempuan. Agus menanggapi jawaban dari Basuki (Ahok), di dalam pandangan Agus, Sikap Ahok yang pernah memarahi seorang ibu-ibu di balai Kota DKI Jakarta beberapa waktu lalu. 
"Pak Basuki, bicara kita Fitnah, yang jelas itu semua sudah diketahui publik, viral-viraal dimana-mana dan itu bukan Hoax, ada di mana-mana bapak mempertontonkan kekerasan verbal dan lisan terhadap kaum perempuan yang harusnya dihormati. Judgment di depan publik, bapak tidak ingat bahwa kekerasan verbal seringkali lebih menyakitkan dari kekerasan fisik, apalagi-apalagi ketika dipamerkan kedepan publik terekam selama-lamanya. Bayangkan kalau itu terjadi pada keluarga bapak, bayangkan kepada keluarga dekat kita, bagaimana kemudian memiliki integritas untuk mengatakan kita akan melindungi perempuan dan anakanak. Sulit mempercayai ketika itu yang dipertontonkan kepada publik" (Sumber: Video Debat)

Retorika Demonstratif, tipe retorika demonstratif ini lebih pada wacana yang memuji dan menjatuhkan. Retorika jenis ini dapat ditemukan pada pasangan Agus-Silvy pada saat sesi-sesi interaksi dan tanggapan, dimana baik agus maupun Silvy tidak pernah mengeluarkan statemen yang mengarah pada kata-kata pujian kepada pasangan incumbent maupun kandidat lainnya. Salah satunya adalah ketika memberikan tanggapan balik kepada jawaban pasangan BasukiDjarot ketika program Agus-Silvy terkait penambahan CCTV di berbagai tempat dan lokasi ruang publik di jakarta dikritik oleh kandidat petahana.

"Bapak (Ditujukan Kepada Basuki Tjahaja Purnama) mengatakan ada banyak program bagus-bagus, sebetulnya dari program bapak tidak ada yang baru, saya mengatakan juga CCTV adalah tambahan-tambahan baru yang belum semuanya terpasang. Kita tau tidak ada program satupun yang baru sama sekali, tapi kita bertanya dimana goodwill, komitmen ingin mengatakan meninggikan perempuan ketika bapak sendiri memaki-maki wanita di depan publik". (Sumber: Video Debat)

\section{2) Basuki Tjahaja Purnama-Djarot Saiful Hidayat}

Retorika Deliberative, retorika tipe ini, fokusnya pada apa yang akan terjadi di masa depan jika ditentukan kebijakan tertentu. Seorang politisi dituntut untuk mampu menciptakan dan memodifikasi pengharapan atas hal-hal yang akan datang. Retorika deliberative dari pasangan Ahok-Djarot dapat dilihat pada sesi interaksi antar kandidat, dimana Ahok menanggapi jawaban Anies terkait dengan kebijakan perumahan DP 0\% yang digagas Anies jika terpilih jadi gubernur DKI. Jika kebijakan itu diterapkan maka dampaknya dari segi regulasi, pendanaan, siapa yang akan menanggungnya.

"Nah yang kami Tanya kalau seandainya, membangun rumah susun ukuran 36 saja itu kira-kira 300 juta, kalau tanpa DP saja, tanpa bunga saja, diangsur oleh rakyat Jakarta warga DKI, 30 tahun itu harus ngeluarkan 833 ribu perbulan, ini masalah buat orang yang gajinya pas-pasan 3 juta, karena komponen kebutuhan hidup layaknya tidak ada. Makanya kami memberikan solusi untuk orang yang gaji di bawah itu disediakan rumah susun, nggak usah sewa, hanya bayar 5-10 ribu perhari sebagai iuran gitong royong. Jadi belum lagi kita berbicara, apakah boleh DPRD ngizinkan, ngutangin warga 30 tahun itu udah ganti berapa kali ganti gubernur, belum lagi perbankan, perbankan maksimal kasih hanya 15 tahun, kalau dibilang subsidi pun, subsidinya, mau subsidi di mana, mau bangun 1 unit saja 3 ratus juta, mau bangun berapa, 10 ribu tiga triliun, uangnya dari mana dikasih begitu nggak bisa, jadi itu yang kami maksudkan" (Sumber: Video Debat).

Retorika Forensik, berfokus pada apa yang terjadi pada masa lalu untuk menunjukkan bersalah atau tidak bersalah, pertanggungjawaban, atau hukuman dan ganjaran. Dari pesanpesan dan komitmen politik yang dielaborasi pasangan nomor urut dua pada saat debat berlangsung, peneliti menemukan satu komitmen dan pendirian pasangan yang diusung koalisi partai politik pro penguasa ini. Djarot misalnya, menyampaikan pembelaan terhadap kekeliruan yang pernah dilakukan oleh Ahok saat memarahi ibu-ibu di Balai Kota.

"Begini yaa, tadi disampaikan dengan sangat kacau, antara perempuan, satu perempuan, kaum perempuan berbeda. Ketika ada ketidak jujuran, untuk mendidik perlu kata-kata tegas dan jelas, sehingga benar-benar kita akan didik mempunyai moral yang jujur, moral yang 
bertanggung jawab, tetapi yang perlu saya sampaikan disini adalah bukankah pak Ahok sudah menjadi Basuki. Sehingga proses belajar ini menjadi bagian yang terpenting bagi kita untk benar-benar melakukan tindakan-tindakan korupsi, kami betul-betul sangat anti korupsi, kami sangat anti terhadap peneyelewengan. Oleh sebab itu, untuk memberikan pendidikan, perlu di Jakarta ada shock terapi supaya masyarakat betul-betul mampu bertanggung jawab, sekarang data menunjukkan sudah hamper tidak ada lagi penyalahgunaan untuk menggunakan KJP, tidak ada yang kontan lagi, artinya apa? KJP betul-betul diperuntukkan bagi kepentingan anaknya, bukan untuk kepentingan ibunya". (Sumber: Video Debat).

Retorika Demonstratif, tipe retorika demonstratif ini lebih pada wacana yang memuji dan menjatuhkan. Penerapan retorika tipe ini, pada pasangan calon incumbent ini banyak ditemukan pesan-pesan politik yang menjurus pada menjatuhkan dan mematahkan programprogram politik pasangan calon lainnya. Kalimat-kalimat menjatuhkan bisa didapatkan baik pada sesi pertanyaan maupun jawaban atau tanggapan dari Basuki-Djarot. Jawaban Ahok pada sesi tanggapan atas pertanyaan dari tim panelis dan jawaban dari kandidat nomor 1 dan 3 ini adalah salah satu contohnya.

"Yaa saya kadang-kadang mohon maaf pada pasangan calon nomor 1 dan nomor 3, kadang-kadang saudara ini suka membangun opini yang menyesatkan sebtulnya, saya kasih lihat yaa..!. ini kami telah memasang contoh dari jepang (sambil menunjukkan gambar) kanapa butuh eskes, supaya motor tidak bisa lewat, kursi roda masih lewat, ini ada standar di Jakarta, dan dewan di transportasi kami, ada perwakilan disabilitas duduk di dalam, makanya jangan heran, kami sudah membeli banyak Bus yang suhu braker nya bisa miring, supaya apa kursi roda turunnyapun rata, itu suspensinya tambah $1 \mathrm{M}$, demi penyandang disabilitas. Lalu bicara CCTV, waduuh, kami ini sdah punya 5.447 CCTV yang terintegrasi di dalam smart city, jadi kita ini, banyak sekali, pasangan calon yang dua ini cerita yang sudah kami kerjakan. Ini toilet (sambil menunjukkan gambar) di taman kami semua. Semua harus syarat ada penyandang disabilitas, ini sangat jelas. Dan tadi bu silvy mengatakan tidak ada PNS yang kerja, saya dalam hati astagaa, Bu Silvy ini kemana aja, kita ini ada 1\% PNS itu ada penyandang disabilitas di DKI lho, makanya untuk Undang-undang yang baru kami akan tingkatkan $2 \%$, bahkan saya pernah belikan mesin kursi roda pada PNS yang bekerja di DPRD dulu, lalu kami pindahkan ke Kominfo. Jadi saya bingung, kalau mengatakan tujuan PKK dibatasi, waduuh, justru PKK inilah yang menghasilkan 600 ribu data rumah tangga dan PKK sekarang gunakan aplikasi, jadi yang tersingkir itu yang tidak mau berubah, jadi mohon maaf banyak data yang sesat"' (Sumber: Video Debat).

\section{3) Anis Rasyid Baswedan - Sandi Salahuddin Uno}

Retorika deliberative, Penerapan retorika deliberative dalam pasangan Anies-Sandi dapat ditemukan pada beberapa statemen dan komitmen politik kedua kandidat yang bersahabat ini. Contohnya adalah pada program-program yang memberikan harapan pada pemberdayaan perempuan di DKI Jakarta yang berbasis wirausaha, pasangan ini memberikan harapan kepada masyarakat DKI Jakarta dengan program Oke-Oce, maupun program Rumah dengan DP 0\%.
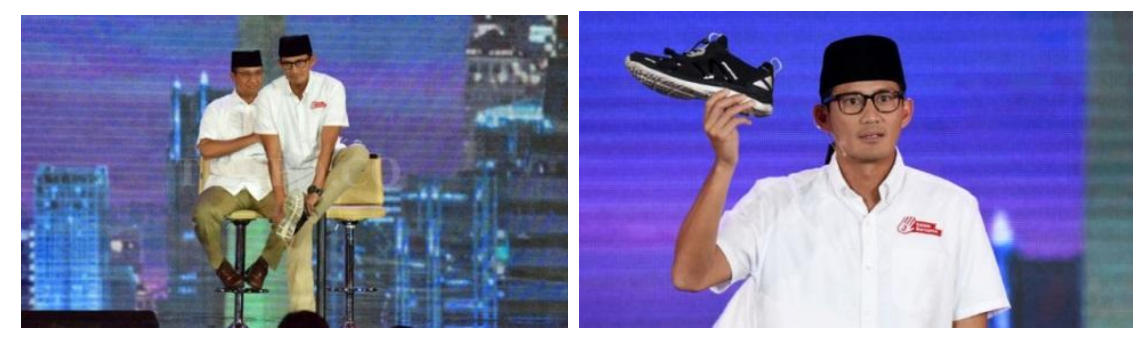

' Kita harus menciptakan lapangan pekerjaan, bagaimana menciptakaan lapangan pekerjaan Oke-Oce. Ok-Oce itu kita ciptakan untuk memastikan bahwa anak-anak muda kita bisa bertumbuh. Saudara Hartono, begitu kita mulai lima ribu lebih daripada peserta oke-oce, salah satunya Hartono yang menciptakan sepatu ini (sambil membuka spatu dari kakinya). 
Sepatu ini adalah sepatu milik bangsa kita, bisa bersaing-bisa bersaing dan kita lihat luar biasa anak-anak kita bisa menyebarkan pertumbuhan di seluruh wilayah Jakarta. Bukan hanya di Tamrin dan Sudirman, tapi juga di condet, di warakas, kita juga melihat pertumbuhan di pesanggrahan, kita juga melihat bagaimana pertumbuhan di daerah tambora, kita juga banyak sekali melihat bahwa saat ini kewirasusahaan itu kini sudah menjadi sebuah fenomena dan kita akan maju terus dengan program Oke-Oce (sambil masih menenteng sepatu di tangan)"'(Sumber: Video Debat).

Retorika Forensik, berfokus pada apa yang terjadi pada masa lalu untuk menunjukkan bersalah atau tidak bersalah, pertanggungjawaban, atau hukuman dan ganjaran. Pada tipe ini, dalam debat terakhir putaran pertam pilgub DKI Jakarta 2017, Anies mengeksplorkan dihadapan public pemilih baik yang ada di lokasi debat maupun penonton debat. Penggunaan retorika tipe ini oleh Anies penulis temukan pada saat penyampaian visi-misinya terkait masalah kependudukan. Pada sesi pertama debat putaran terakhir, retorika Anies pada saat menyampaikan pesan dan komitmen politiknya dapat dinilai sebagai tipe retorika Forensik.

' 'Ijinkan kami menegaskan, bahwa Jakarta hari ini adalah kota yang tidak ramah anak, tidak ramah perempuan, tidak ramah warga dipabel, dan amat ramah terhadap Narkoba. "kami akan membalikkan itu semua" menjadi kota yang ramah anak, ramah kaum dipabel, ramah perempuan, dan tidak ramah sama sekali pada narkoba. Itu yang akan kami lakukan. Kenyataan menunjukkan, dan ini bukan salah pak gubernur. Ini fakta yang sudah lama ada di tempat ini, ini adalah potret Jakarta, Jakarta kita semua! Mari kita lihat di sini (sambil mengambil dan menunjukkan alat peraga) 'Kaum perempuan di media transportasi, kita terburuk nomor lima di dunia, kita di bawah malaysia, di bawah kualumpur, di bawah manila, di bawah bangkok" 'Lalu kita lihat sekarang Narkoba, naik signifikan, 35\% dalam satu tahun" saudara sekalian ini bukan angka statistik, ini adalah perasaan menderita yang dialami oleh warga Jakarta dan keluarga-keluarga Jakarta. (sambil menunjukkan alat peraga). Karena itu kami akan berpihak pada perempuan, kami akan berpihak pada kaum dipabel, dan kami akan tegaskan keberpihakan kita, kami akan undang mereka terlibat, caranya kami nggak mau sok tahu, mereka yang sudah lama terlibat di sini kami undang, mari kita susun kebijakan sama-sama. Kita laksanakan sama-sama ide dari mereka, keberpihakan dari kami (Sumber: Video Debat).

Retorika Demonstratif. Dilihat dari pesan-pesan dan komitmen politik yang dipaparkan Anies, penulis menemukan penerapan ini pada saat Anies memberikan tanggapan atas pertanyaan dari panelis dan tanggapan terhadap jawaban dan komitment kandidat pasangan calon lainnya.

' 'Ketika berbicara tentang kebutuhan disabilitas, maka apa yang disampaikan tadi baik, tapi semuanya mengasumsikan bahwa saya, kami tau semua solusi, padahal tidak dan menyangkut disabilitas sudah begitu banyak contoh praktek terbaik di dunia, standarnya ada prosedurnya ada. Di kita adalah justru melibatkan, dan komitmen kami, ini yang berbeda, kami dalam semua kebijakan kedepan, akan mengajak warga penyandang disabilitas untuk terlibat dalam penhyusunan nya, sehingga tidak terjadi lagi peristiwa seperti ini (sambil mengambil dan memperlihatkan gambar atau data). Contoh, koridor 13 Bus Way kita ada 10 halte di koridor 13 dan dari 10 halte itu, hanya 1 Yang menggunakan Ram, yang lainnya hanya menggunakan tangga, efeknya apa? Penyandang disabilitas, ibu hamil, mereka yang dateng dengan membawa kursi bayi, semuanya tidak bisa memanfaatkan pasilitas ini, dan ini dibangun baru-baru ini, bukan dibangun 10-5 tahun lalu' (Sumber: Video Debat).

Dari paparan pesan dan komitmen politik Anies tersebut, Anies menegaskan keburukan sistem transportasi yang dibangun pada masa calon incumbent saat ini. Penggalan kalimat di atas tentu menjatuhkan kinerja calon gubernur dan calon wakil gubernur petahana.

'Penyandang disabilitas, ibu hamil, mereka yang dateng dengan membawa kursi bayi, semuanya tidak bisa memanfaatkan pasilitas ini, dan ini dibangun baru-baru ini, bukan dibangun 10-5 tahun lalu" (Sumber: Video Debat). 


\section{Tipe Orasi Politik Cagub - Cawagub DKI Jakarta 2017}

Setiap kandidat ataupun politikus senantiasa menyadari tipologi orator yang sedang diperankannya saat tampil di panggung debat. Dalam Public Relations, ada tiga tipe orator politik:

Pertama, Noble Selves: Orator yang menganggap dirinya paling benar, mengklaim lebih hebat dari yang lain dan sulit menerima kritik. Jika tipe ini yang ada dalam diri praktisi Public Relations Politik, maka tentu akan menghambat proses Public Relations politik yang sedang dilakukan. Kedua, Rhetorically Reflector: Orator yang tidak punya pendirian yang teguh, hanya menjadi cerminan orang lain. Tipe seperti ini akan melemahkan lembaga atau kandidat, karena orator tak memiliki kapasitas untuk membangun diskursus, berpolemik atau mempertahankan ide dan konsep. Dia tak lebih dari sekedar cerminan kepentingan pihak lain. Ketiga, Rhetorically Sensitive: Orator yang adaptif, dan cepat menyesuaikan diri dengan lingkungannya. Ini merupakan tipe ideal karena tahu bagaimana dan kapan harus memainkan diri publik (Public Self) dan diri pribadi (Private Self). Cenderung fleksibel, tetapi memiliki konsep diri yang jelas, sehingga bisa menunjukkan ketegasan dan kewibawaannya di depan khalayak.

Dilihat dari pesan-pesan politik dan gaya pemaparan setiap kandidat cagub DKI 2017 dalam debat, ketiga kandidat cagub-cawagub dapat dikategorikan kedalam tiga tipe.

\section{1) Pasangan Agus Harimurti Yudhoyono dan Silvyana Murni}

Dilihat dari pesan-pesan dan komitment politiknya yang tidak begitu tajam dan lebih cenderung mengedepankan hafalan, serta dengan data lapangan yang minim, pasangan ini dapat dikategorikan ke dalam tipe orator Rhetorically Reflector. Setelah penulis lakukan pengamatan baik di lokasi debat maupun menonton ulang video siaran langsung debat dari TVOne, pasangan calon ini sangat tepat dan pas dimasukkan ke dalam Rhetorically Reflector. Pasangan ini tidak punya pendirian yang teguh, hanya menjadi cerminan orang lain. Tipe seperti ini akan melemahkan lembaga atau kandidat sendiri bila terpilih sebagai gubernur, karena orator tak memiliki kapasitas untuk membangun diskursus, berpolemik atau mempertahankan ide dan konsep. Dia tak lebih dari sekedar cerminan kepentingan pihak lain.

Keberadaan Silvyana Murni sebagai pendamping Agus, yang awalnya akan mampu membantu kekurangan Agus saat debat antar kanididat malah cenderung mengeluarkan statemen yang melemahkan pasangan ini, misalnya ketika Silvyana Murni menyatakan bahwa ' 'ada $g$ sih yang namanya penyandang disabilitas bekerja di balai Kota'?

Statemen ini sangat fatal bagi kandidat nomor urut 1 ini, karena nyaris mengeluarkan pesan dan komitmen politik tanpa data yang akurat. Kemudian langsung ditanggapi oleh pasangan Nomor Urut 2 Basuki Tjahaja Purnama ' Astaga, Bu Silvy ini ngapain aja selama ini, $1 \%$ dari PNS DKI Jakarta itu ada khusus jatah penyandang Disabilitas" tegas peria yang dipanggil Ahok ini.

Bahkan yang lebih miris lagi, ketika Ahok menambahkan bahwa 'Ibu Silvy ini tipe Pegawai yang tidak mau care dengan PNS golongan rendah, sehingga dia tidak kenal'”.

Jawaban dari Basuki tersebut, dalam pandangan penulis sebagai peneliti adalah kartu merah bagi pasangan Agus-Silvy dan melemahkan espektasi pemilih untuk mendukung kandidat ini.

\section{2) Pasangan Basuki Tjahaja Purnama dan Djarot Saiful Hidayat}

Paslon Ahok-Djarot dapat dikategorikan sebagai orator Noble Selves. Pasangan ini lebih kerap kali mengeluarkan pesan-pesan dan statemen politik yang mengarah pada sikap menganggap dirinya paling benar, mengklaim program-program kerjanya lebih hebat dari pasangan calon yang lain dan sulit menerima kritik. Pernyataan dan pesan-pesan politik yang disampaikan saat debat terakhir pada putaran pertama pilgub DKI 2017 oleh pasangan BasukiDjarot tentu menghambat proses Public Relations politik yang sedang dilakukan oleh diri dan timnya. Karena pemilih di DKI Jakarta tergolong rasionalis dan susah diprediksi kemana arah 
mayoritas dukungannya, maka statemen-statemen yang mengarah pada pembenaran diri menjadi salah satu faktor pemilih beralih dukungan ke kandidat lainnya.

Ada beberapa beberapa pernyataan Basuki maupun Djarot pada saat sesi interaksi antar kandidat, yang cenderung mengarah pada pembenaran diri serta menganggap program paslon lain tidak berkualitas. Seperti statemen Ahok yang menilai program kandidat lain hanya sebatas janji.

' 'Tapi tolonglah pasangan satu dan tiga ini ibarat om tante yang datang ke rumah dia pingin dapat simpati sama anak-anak kita lalu semua di boleh-bolehin, mau kasih 1 Milyar yang nggak jelas, mau dikasih rumah yang murah, padahala nggak bisa dicicil saja tidak mampu', Incubator, berapa ratus ribu tiap bulan, gaji pas-pasan, mana bisa cicil rumah 800 ribu, maka saya katakan, "janganlah karena ingin jadi gubernur, ini ibarat om sama tante merusak aturan yang sudah dibuat oleh orang tua, mendidik anak itu susah, membangun itu gampang, medidik anak itu bertahun-tahun, kami ingin warga DKI yang sudah kami dididik dengan baik, jangan dirusak gara-gara pingin jadi gubernur saja",

Sebelumnya, Djarot juga menyinggung bahwa program kandidat lainnya juga cenderung di awing-awang yang sulit di implementasikan di lapangan.

' 'Untuk paslon 1, mereka berani menyampaikan sesuatu meskipun secara lapangan, aksi di lapangan itu sulit untuk dilaksanakan, tapi yakin banget, yakin banget. Untuk paslon nomor 2 (mengarah kepada paslon Nomor 3), itu lebih hebat lagi, pandai membikin suatu opini di awang-awang tetapi bukti-buktinya susah".

3) Pasangan Anies Rasyid Baswedan dan Sandiaga Salahuddin Uno

Bila dicermati dari pernyataan, pertanyaan, jawaban dan sanggahan terhadap pertanyaan dari dan untuk pasangan ini. Penulis menempatkan pasangan nomor urut 3 ini pada tipe orator Rhetorically Sensitive. Orator yang adaptif, dan cepat menyesuaikan diri dengan lingkungannya. Pasangan ini memiliki komitmen yang tinggi untuk mengikutkan masyarakat terlibat aktif dalam memberikan masukan untuk program kerja kedepan. Ini merupakan tipe ideal karena faham bagaimana dan kapan harus memainkan diri publik (Public Self) dan diri pribadi (Private Self).

Cenderung fleksibel, tetapi memiliki konsep diri yang jelas, sehingga bisa menunjukkan ketegasan dan kewibawaannya di depan khalayak. Contohnya, ketika ditanya terkait dengan pengarus utamaan Gender dalam pembangunan DKI Jakarta. Anies menegaskan bahwa:

'Prinsip kita adalah kami akan melibatkan mereka-mereka yang sudah bergerak di dalam tema perempuan dan pemberdayaan perempuan, mengapa? Saya pernah di birokrasi, kami di birokrasi memiliki kemampuan untuk menggandakan, tetapi bicara dan inovasi terobosan, maka warga biasanya justru memiliki lebih banyak terobosan, oleh karena itu maka pendekatan kami komit untuk pemberdayaan perempuan, caranya kami akan mengajak organisasi-organisasi perempuan dan tidak ada kota di Indonesia yang memiliki organisasi aktivis sebanyak di Jakarta, libatkan mereka, komitmennya di kita".

\section{Kesimpulan}

Kesimpulan ini merupakan sebagai hasil temuan dan analisis terhadap data-data retoris yang berkaitan dengan aktivitas retorika politik ketiga pasang calon Gubernur dan Wakil Gubernur DKI Jakarta 2017 dalam debat terakhir sebelum pemilihan putaran pertama digelar. Kesimpulan ini merujuk kepada penerapan prinsip-prinsip retorika politik, dan perbedaan serta persamaan retorika ketiga pasang calon selama debat antar kandidat. Beberapa pointer utama dari hasil analisa penelitian ini adalah:

Dari penampilan orasi ketiga cagub-cawagub DKI Jakarta 2017 pada saat debat berlangsung semuanya mampu menerapkan prinsip-prinsip retorika politik dengan baik dan sempurna. Aspek- 
aspek retorika secara umum, seperti etos, pathos dan logos dimiliki oleh semua kandidat, sehingga penampilan ketiga pasang calon gubernur dan wakil gubernur bila dinilai dari penggunaan prinsipprinsip retorika aristoteles nyaris sempurna dipraktekkannya. Seperti, Inventio (Penemuan), Disposito (penyusunan), Elocutio (Gaya), Memoria (Memori), Pronountiatio (Penyampaian).

Sehingga kemampuan retorika ketiga kandidat cagub-cawagub DKI Jakarta 2017 masingmasing dapat dinilai bahwa gaya retoris pasangan Agus Harimurti Ydhoyono dan Silvyana adalah tipe orator Rhetorically Reflector, Kemudian pasangan Basuki Tjahaja Purnama-Djarot Saiful Hidayat, dapat digolongkan pada tipologi orator Noble Selves. Pasangan ini lebih kerap kali mengeluarkan pesan-pesan dan statemen politik yang mengarah pada sikap menganggap dirinya paling benar, mengklaim program-program kerjanya lebih hebat dari pasangan calon yang lain dan sulit menerima kritik. Adapun pasangan Anies Rasyid Baswedan-Sandiaga Salahuddin Uno, peneliti menyebutnya tipe orator Rhetorically Sensitive.

Kesimpulan yang kedua adalah pasangan cagub-cawagub DKI Jakarta 2017 yang berkompetisi mengeksplorkan visi-misi, program dan gagasan dalam debat antar kandidat, memiliki sisi persamaan dan sisi perbedaan. Retorika Pasangan Agus Harimurti YudhoyonoSilvyana Murni, pada saat debat terakhir putaran pertama, tidak memiliki perbedaan signifikan dalam hal penampilan, gestur tubuh dan pesan-pesan politik yang disampaikan sama dengan kedua pasangan calon gubernur dan wakil gubernur DKI Jakarta 2017 lainnya. Perbedaan mendasar pasangan Agus-Silvy dengan kandidat lainnya adalah pasangan ini minim data sebagai penyeimbang pesan dan komitment politik untuk membangun Jakarta. Adapun retorika politik Pasangan Basuki Tjahaja Purnama-Djarot Saiful Hidayat, memiliki keunggulan dari aspek kemampuannya menampilkan data-data yang disinkronkan dengan pesan-pesan politik. Sedangkan retotika politik pasangan Anies Rasyid Baswedan-Sandiaga Salahuddin Uno. Kekuatan pasangan ini pada kemampuannya menguasai panggung komunikasi, dengan bahasa-bahasa yang mudah difahami, dan data-data yang sudah dipersiapkan, menjadikan penampilan retorika politiknya lebih meyakinkan masyarakat pemilih Jakarta. Ekspresi gestur Sandi Uno yang mencobot sepatunya secara spontanitas ketika menjelaskan keunggulan program Oke-Oce yang digagasnya menjadi salah satu momen yang mampu mempersuasi pemilih.

\section{DAFTAR PUSTAKA}

Arifin, Anwar. (2011). Komunikasi Politik Filsafat-paradigmatik-teori-tujuan-strategi dan komunikasi politik di Indonesia, Graha Ilmu, Yogyakarta.

Bajari, Atwar, (2015). Metode Penelitian komunikasi prosedur, trend an etika. Simbiosa Rekatama Media. Bandung.

Budiardjo, Miriam 2000. Pengantar Ilmu Politik, Gramedia, Jakarta.

Budiarjo, Miriam. (1994). Demokrasi di Indonesia: Demokrasi Parlementer dan Demokrasi Pancasila (Kumpulan Karangan), Gramedia, Jakarta.

Bungin, Burhan. (2006). Metodologi Penelitian Kualitatif: Aktualisasi Metodologis ke Arah Ragam Varian Kontemporer, PT. Raja Grafindo Persada, Jakarta.

. (2001) Metodelogi Penelitian Sosial, Airlangga University Press, Surabaya.

Cangara, Hafied. (2009). Komunikasi Politik, PT. Raja Grafindo Persada, Jakarta.

2013. Perencanaan dan Strategi Komunikasi. Raja Grapindo Persada Jakarta.

Chalid, Fheni (2005). Pilkada langsung Demokratisasi Daerah dan Mitos Good Governance. Pusat Kajian Politik, Departemen Ilmu Politik UI. Jakarta. 
Creswell, John W. terj (A. Lintang Lazuardi), (2015). Penelitian kualitatif, dan Desain Riset, memilih diantara lima pendekatan. Pustaka Pelajar, Yogyakarta.

Danim, Sudarwan. (2002). Menjadi peneliti Kualitatif, Pustaka Setia Bandung.

Effendy, Onong Uchana. (2008). Dinamika Komunikasi, Rosda Karya. Bandung.

Hendrikus, Dori Wuwur (1991). Retorika: Terampil berpidato, Berdiskusi, Berargumentasi, Bernegosiasi. Penerbit Kanisius. Yogyakarta.

Heryanto, Gun Gun dan Zarkasy, Irwa. (2012). Public Relations Politik, Ghalia Indonesia. Bogor.

Heryanto, Gun Gun dan Farida, Ade Rina. cet. 1, (2011). Komunikasi Politik. Lembaga Penelitian UIN Syarif Hidayatullah. Jakarta.

Hidayat, Dedi N. (2003). Metode penelitian kualitatif, Citra Aditya Bakti, Bandung.

Gabriel A, Almond dan Sidney Verba. (1990). Budaya Politik Tingkah Laku Politik dan Demokrasi di Lima Negara. Bumi Aksara Jakarta.

Kaid, Lynda Lee (Editor). (2004). Handbook Of Political Communication Research. Lawrence Erlbaum Associates Publishers. London.

Keraf, Gorys. 2007. Diksi dan Gaya Bahasa. Gramedia, Jakarta.

Kriyantono, Rachmat. (2012). Teknik Praktis Riset Komunikasi, Kencana Prenada Media, Jakarta.

LittleJohn, Stephen W. \& Foss, Karen A. (2012) (edisi terj): Teori Komunikasi Theories of Human Communication. Salemba Humanika. Jakarta.

Malik, Dedy Jamaludin (Editor). (1993). Komunikasi Persuasif, PT. Remaja Rosdakarya, Bandung.

Mulyana, Dedy. (2004). Komunikasi Populer Kajian Komunikasi dan Budaya Kontemporer, Pustaka Bani Quraisy, Bandung.

Mulyana, Deddy dan Solatun (2013) cet.13. Metode Penelitian Komunikasi. Remaja Rosdakarya. Bandung.

Morissan dan Andy Corry, 2009. Teori Komunikasi: Komunikator, Pesan, Percakapan, dan Hubungan. Ghalia Indonesia: Bogor.

Nimmo, Dan. (1989) Komunikasi Politik: Komunikator, Pesan, dan Media, PT. Remaja Rosdakarya. Bandung.

Nurudin, 2005. Sistem Komunikasi Indonesia. PT. Raja Grapindo Persada. Jakarta.

Nimmo, Dan. (2001). Komunikasi Politik: Khalayak dan Efek, Rosda Karya, Bandung.

Rush, Michael \& Phillip Althoff. (2001). Pengantar Sosiologi Politik, Rajawali Press, Jakarta.

Rakhmat, Jalaluddin, (2000). Retorika Modern: Pendekatan Praktis. PT Remaja Rosdakarya. Bandung.

Rakhmat, Jalaluddin, dan Idi Subandy Ibrahim, (2016). Metode Penelitian Komunikasi. Simbiosa Rekatama Media. Bandung. 
Schroder, Peter. 2008. Strategi Politik. Edisi Revisi untuk Pemilu 2009 (Diterjemahkan oleh Denise J. Matindas \& Irina Dayasih). Friedrich-Naumann-Stiftung. Jakarta.

Subiakto, Henry. (2012). Komunikasi Politik, Media \& Demokrasi, Kencana Prenada Media Group, Jakarta.

Suhandang, Kustadi. (2009) Retorika Strategi Teknik dan Taktik Pidato, Nuansa Bandung.

Suharsaputra, Uhar. (2012). Metode Penelitian Kuantitatif, Kualitatif, dan Tindakan, Refika Aditama, Bandung.

Surbakti, Ramlan. (1992). Memahami Ilmu Politik, Gramedia. Jakarta.

Susanto, Eko Harry. (2009). Komunikasi Politik dan Otonomi Daerah, Mitra Wacana Media, Jakarta.

Uchana, Onong. Cet.23 (2011). Ilmu Komunikasi Teori dan Praktek. Remaja Rosdakarya, Bandung.

Pawito. (2009). Komunikasi Politik: Media Massa dan Kampanye Pemilihan, Kalasutra. Yogyakarta.

West, Richard. \& Turner, Lynn H. (2008). Pengantar Teori Komunikasi: Analisis dan Aplikasi Buku Kedua. Salemba Humanika, Jakarta.

\section{Sumber dari Jurnal Online,}

I Nengah Martha, PRASI Vol. 6, No. 12 Juli - Desember 2010.

Gigih Mardana, Komunikasi Politik di Media Massa, Jurnal Komunikasi Massa Vol 3 No 2 Juli 2010.

Kamarudin Hasan, Komunikasi Politik dan Pencitraan Politik, Jurnal Ilmu Politik dan Ilmu Pemerintahan Volume 2, No. 4, Desember 2009 ISSN: 1979 - 0899 Universitas Maritim Ali Haji.

Tuty Mutiah Dengan judul 'Gaya Retorika Jokowi Dalam Program Debat Kandidat Putaran Kedua Calon Gubernur Dan Wakil Gubernur DKI Jakarta Di Jak TV 2012. Dalam Jurnal BSI.

\section{Sumber Skripsi dan TESIS,}

Choiru Pradhono, berjudul "Retorika" Parodi Pidato Politik Dalam Seni Instalasi Vide . Pertanggungjawaban tertulis penciptaan seni pada program penciptaan dan pengkajian Pascasarjana Institut Seni Indonesia (S2 ISI) Yogyakarta 2014.

Yaumul Afifah Berjudul 'Retorika Wacana Kampanye Susilo Bambang Yudhoyono Pada Pemilihan Presiden 2009', Skripsi Pada Program Studi Bahasa Dan Sastra Indonesia Jurusan Bahasa Dan Seni Universitas Jember 2011.

Herdina Rosidi Yang berjudul 'Retorika Politik Kandidat Pemilukada DKI Jakarta: Analisis Komparatif Joko Widodo Dan Fauzi Bowo. Skripsi pada Jurusan Komunikasi dan Penyiaran Islam Fakultas Ilmu Dakwah dan Ilmu Komunikasi Universitas Islam Negeri Syarif Hidayatullah Jakarta 1433 H /2013 M. 
Nicki Hardyanti dalam Jurnal Universitas Sumatera Utara (USU) "Analisis Retorika Dalam Kampanye Pemilukada DKI Jakarta 2012" (Studi Kualitatif Analisis Retorika JokowiAhok Dalam Debat Kampanye Pemilukada DKI Jakarta 2012).

\section{Website}

http://katadata.co.id/infografik/2017/01/27/perang-lembaga-survei-di-pilkada-dki.

http://www.posmetro.info/2016/12/wow-hasil-survei-kompas-ahok-keok-agus.html.

http://megapolitan.harianterbit.com/megapol/2016/09/23/69363/0/18/Pilkada-DKI-Ini-Biografi-

Pasangan-Letkol-Agus-Dr.-Hj.-Sylviana-Murni.

http://www.rappler.com/indonesia/data-dan-fakta/158528-visi-misi-agus-sylviana-pilkada-dki2017.

https://m.tempo.co/read/news/2016/09/23/083806714/profil-agus-sylviana-tentara-akademisi-danbirokrat-tulen.

http://megapolitan.kompas.com/read/2017/02/02/16154991/tema.debat.ketiga.cagub-cawagub dki soal kependudukan dan peningkatan kualitas hidup diakses tanggal 02 Maret 2017 pukul 20.00 WIB.

https://news.detik.com/berita/d-3438375/kpu-tetapkan-ahok-djarot-dan-anies-sandi-maju-putarandua-pilkada diakses tanggal 5/3/2017 pukul 20:00 WIB.

http://www.rappler.com/indonesia/data-dan-fakta/158530-visi-misi-ahok-djarot-pilkada-2017.

\section{Sumber-sumber lain}

Buku visi-misi Agus-Slivy ''Menuju Jakarta 22 Yang Lebih Maju, Aman, Adil dan Sejahtera'.

Sumber: Visi, Misi, Dan Program Kerja 2017-2022 Basuki Tjahaja Purnama-Djarot Saiful Hidayat.

Buku Visi-Misi Anies Sandi Tuntas Ikhlas Untuk Jakarta.

Pesan politik Sandi, pada saat debat terakhir putaran pertama pilgub DKI Jakarta 2017.

Video debat terakhir putaran pertama pilgub DKI Jakarta 2017, diambil dari video Asli milik TV One. Yang belum pernah di edit kecuali pada bagian iklan.

Video debat terakhir putaran pertama pilgub DKI Jakarta 2017, diambil dari video Asli milik TV One. Yang belum pernah di edit kecuali pada bagian iklan.

CD Video Debat Terakhir di TVOne. 